\title{
Monk as Reluctant Cataloguer
}

by Placid Spearritt; edited by Philip Harvey

Sue Johnson of the New Norcia Library, Western

Australia, has been assisting in the collation and archiving of the papers of Placid Spearitt, Abbot of New Norcia Abbey. This follows his death in 2008 at Ampleforth Abbey in England on the 4th of October. Two papers on librarianship have surfaced, which I have transcribed and edited. 'Confessions of a Bibliophile Monk' is an address he gave in 1997 and it appears elsewhere in this journal. It makes good comparative reading with an untitled address of 1993, that I have riskily titled 'Monk as Reluctant Cataloguer'. It was the Conference Dinner speech to the Australian Library and Information Association (ALIA) Cataloguing Conference in Fremantle, 5th of November 1993.

$\mathrm{T}$ his earlier paper, in part autobiographical, is written in note form. Placid thought on his feet, so we'll never know everything he said that night. I have reconstructed the notes using his own genial words as much as possible, even including the mandatory warm-up jokes. All editorial reconstruction is in italics.

Brevity is the soul of wit and Placid could keep it brieffor hours on end. He opened by saying that he normally liked to speak freely when away from home but that he was scared to speak in front of his fellow monk, Dom Chris Powers, who must have been present, because Chris is the procurator. Pontius Pilate, he reminded the librarians, was procurator in Judaea.

Dom Chris specialises in marketing, commercial promotion. I'm the spiritual half: I seek the kingdom of heaven, while Chris sees to it that all the other things are added unto us.

Placid said he normally begins speeches away from home with an explanation of his funny name, 


\section{"I could supply a} few uncontrolled subjects, not sure who would want access to them."
Placid Spearritt. He felt a fair number of people would have heard that story probably several times, so "ask your neighbour afterwards." He then added that he "might write a pamphlet on the subject," it being unclear if this was a promise or a threat. He thought instead of opening by explaining his title of Prior Administrator. A Prior Administrator is "a kind of temporary abbot: a superior who doesn't have tenure: easier to get rid of than an abbot." Theoretically he has all the same powers and probably so in practice too. An abbot theoretically has a lot of powers but in practice it "depends on how much the monks want to take notice of him." Placid became Abbot in January 1997.

Older monastic literature uses the terms 'superior' and 'subject' fairly freely. I prefer 'prior' and 'monk' myself. 'Superior' makes the rest sound inferior, 'subject' makes the boss sound a little too monarchical. No matter what you call the personnel, the problem's much the same. [I was] interested to see on the brochure calling for papers, one of the suggested themes was uncontrolled subject access. I could supply a few uncontrolled subjects, not sure who would want access to them. [I was] not so impressed by another theme: authority control. I would prefer not to be controlled too much in exercise of my authority.

This brought Placid nearer to the subject of the speech. He had had more than a little difficulty deciding what the subject should be and was "not sure that I've resolved the difficulty." So he hit upon the expedient of inviting the delegates to assign an appropriate subject heading at the end of it, "after all, you're the experts at that game."

This reminded bim of the competition they used to run in the London 'Punch' magazine in which you had to supply a new caption to one of their old cartoons. Placid was well aware that such jokes are mandatory on such occasions, so continued.

The only one I can remember very clearly is slightly improper, so you'd probably like to hear it. Older people will remember what pillar boxes were: large cylindrical iron fixtures where you posted your letters. A man is walking off with an old-fashioned pillar box clasped close to his breast, which he had uprooted bodily from the pavement, it still had concrete attached to its base. His friend is evidently asking what he was doing that for. Old caption: "I posted a letter proposing marriage to my girlfriend, and now I've changed my mind." [This is a] very old cartoon, when people used to propose. New caption: "I've got the damn thing caught in my zip." Perhaps [I] had better change the subject, as they say at cataloguers' conferences. Except that I'd better disqualify one entry for the subject heading for this speech, before you think of it: The Name of the Rose is not available.

Well, monks come a very long time after Abraham, and after Moses, who not only collected the Ten Commandments engraved from on high, [but] in two editions, the second one replacing the first edition, which he broke when he found Aaron and the lads messing about with the golden calf. Moses not only promoted the celestial writing, but also, we are told, wrote the first five books of 


\section{"One of my}

excuses for not

\section{running a very}

comprehensible

libraryat

Ampleforth

was that I was

expected to provide

employment for

sick novices on wet

afternoons." the Bible as well.

Anyway, monks were still a long time in the future then, but when they turned up, Christian ones, from about the fourth century onwards, they were well and truly into the Scriptures, sacred and pretty soon secular as well. They collected them, copied them, memorised them, translated them, and fought over them and their interpretation from that day to this. You may regard interpretation and fighting as the job of the readers in a library, rather than the job of the cataloguers, but obviously you can't catalogue anything accurately, and you certainly can't assign it a subject heading, without interpreting for yourself what it's about. And I imagine there would be no need for conferences like this if there weren't a few potential fights around about what certain books are about and how you choose your subject headings.

Well, to get back to the subject, or one of the subjects, monks have been collecting books for as long as anyone can remember and they've had some weird and wonderful ways of cataloguing and classifying their collections. I was lucky in that before joining my monastery I'd worked for three years as a librarian in the University of Queensland. That was from 1956 to 1958. I started as Periodicals with a staff of two-and-a-half including me, and finished as Orders with a staff of two. I passed a few [preliminary examinations] in the old ALA, but I think I failed in cataloguing.

Those qualifications were considered sufficient for me to be appointed sole cataloguer, and sole everything else in due course, in the Library of Ampleforth Abbey in Yorkshire. Like most untrained or failed librarians, I had strong ideas about cataloguing, and duly implemented them when given my head. But I confess that I never could get to first base with subject headings, and simply didn't use them, with the exception of the subjects of biographies, literary criticism and the like. It didn't affect the clientele very much: most of the monks didn't use the catalogue anyway. If they couldn't find a book on the same shelf where they found it five years ago, they would either ask the librarian, or give up the search.

One of my excuses for not running a very comprehensible library at Ampleforth was that I was expected to provide employment for sick novices on wet afternoons. There are a lot of wet afternoons in Yorkshire, and a lot of novices pretty soon get sick of gardening or going for runs over the moors in wet weather. One sick novice is capable of doing more damage in a library in one hour's work than even a properly trained librarian could repair in a week. I did learn one useful dodge there in the days before I became librarian proper, when I simply did the work, under the direction of my predecessor. Fortunately he was even less trained than I was.

However, he was a tolerably elderly monk, I suppose of about the same age as I am now, and had rather conservative views about theology. He disapproved of the writings of the Protestant existentialist Scripture scholar Rudolf Bultmann, whereas we 


\section{"I used to classify}

Bultmann's

scriptural studies

under some obscure

sub-section of

existentialist

philosophy, to

await the day

when Fr Barnabas

would have moved

on and they could

be transferred to

their rightful class

numbers." youngsters found Bultmann a great deal more interesting than the run-of-the-mill orthodox exegetes. So I used to classify Bultmann's scriptural studies under some obscure sub-section of existentialist philosophy, to await the day when Fr Barnabas would have moved on and they could be transferred to their rightful class numbers. I used to teach philosophy, so I was well aware that hardly anybody browsed in that area at all: if you are a boring enough teacher, you can change the pattern of your students' library usage quite significantly.

So it is from my training, such as it was, at St Lucia in Queensland and at Ampleforth, that I came to be Prior Administrator at New Norcia, at last in a position where I am the supreme authority barring outside intervention if I become too scandalous - and so can really throw my weight around in the monastery library.

The New Norcia Library is fascinating, like all monastery libraries. Like them all, it doesn't have all that a monastery library should have, including essential reference works, because the monastery can't afford them. In most areas it doesn't have whatever you're looking for, but it can always offer something else, off the subject, but much more interesting, instead. Serendipity flourishes.

Much of the stock comes from donations and bequests, which we encourage. For the moment we have plenty of space in an empty classroom block from the College that closed down in 1991. Monks always regard themselves as having plenty of time, not now, but in the future: we tend to think in spans of a couple of hundred years. So we are canvassing convents and parish priests and religious libraries in Perth to direct all their unwanted material our way. My idea is that we will keep for posterity one copy of every differently paginated edition of every religious work that comes our way. I realise that sooner or later we will hit the buffers. The space will run out, the paper will crumble, we will never be able to afford adequate staff or facilities, and so on. But I regard those as problems for one of my successors to deal with.

I am always loath to reveal in the company of professional librarians or archivists this magpie instinct of hanging on to everything and I was amazed when we recently invited the librarians of Perth's tertiary institutions to a day's consultation on the present and future for a regional specialist religious collection in collaboration with the state and national libraries. I was amazed again when our domestic library committee agreed to a proposition that we should accept the donation of all duplicates from the library of the Western Australian Medical Museum. Many doctors bequeath them their books, so they accumulate duplicates at a rate of knots. Our library committee generally does not hesitate to certify me insane, but they too seem to think we might as well build up our stock in all departments from donations, since we cannot afford to spend more than our budgeted $\$ 10,000$ a year on acquisitions of books, periodicals and other media. In the meantime we are developing up a useful trade in the sale 
"There are still a few barbarians around in Western Australia who pose something of a threat to monastic culture in New Norcia, but we are thankful that the library profession in this state is not among them" of duplicates that come in large numbers among the donations we receive.

We have a significant number of early imprints: Hay and Bean in their catalogue, published in 1986, listed 1008 titles in the 2080 volumes. [The early imprints at New Norcia : a bibliographical study of pre-1800 books in the Benedictine Monastery library at Nerw Norcia, Western Australia, by John Hay and David Bean. Perth, Western Australian Institute of Technology, 1986. (Western library studies, 9) ISBN 0908155859] Since then we have found or acquired another four hundred and something volumes. We have employed our first full-time qualified librarian in Trevis Lawton, and he has begun the long task of re-cataloguing the entire library by computer. $\mathrm{He}$ is an enterprising young man, and has invented the annual New Norcia Library Lecture, inaugurated with distinction last month by Dr Ross Harvey. We intend that to be in part a thank-offering contribution to the profession in Western Australia, for all the generous help we continue to receive from its members. We are investigating ways of joining the Australian Bibliographic Network [ABN, i.e the National Database at the National Library of Australia, currently called Libraries Australia. - Ed.] ; and we will continue to work closely with the other members of the Australian and New Zealand Theological Library Association. I would like to thank the staff of the Curtain University School of Information and Library Studies, and the Librarian of Curtin University and her staff, for the exceptional encouragement and assistance they have given us at New Norcia, and for arranging my invitation to speak to you tonight.

In 1980, for the sesquimillenium of the birth of St Benedict, there was an exhibition at the British Library on the Benedictines in Britain. It was opened by Cardinal Basil Hume, formerly abbot of Ampleforth. He said that as his car drove into the courtyard of the British Museum, his monastic heart froze when he saw across the front of the building the banner advertising another exhibition: Vikings. There are still a few barbarians around in Western Australia who pose something of a threat to monastic culture in New Norcia, but we are thankful that the library profession in this state is not among them, nor the intelligent and good-looking members of the profession who come from elsewhere to attend conferences like this one. Thank you. I suspect Dom Chris would want me to say if there is anything you can do for us, we will be most grateful.

In her covering letter to me, Sue Johnson remarks dryly that "library policy in 1993 has evolved considerably." She says that of course the two articles "are not library policy documents," but that they give "great pictures of Placid. His breadth of vision, whimsy and huge tolerance all shine through."

Since then the New Norcia Library has received quite a few other secular collections, the most valuable being a collection of books on the 
early French exploration of Australia, worth about a quarter of a million dollars, donated by Dr. T.B. Cullity in 2007.

The Library's donations policy has expanded since the, New Norcia now receiving materials nationwide. The minutes of the Library Committee Meeting for March 28th 2007 state: "The New Norcia Library will continue to seek donations so that our collection will include at least one copy of every book on religion, regardless of quality. We will limit our future collection of secular books to those of quality in the areas of philosophy, history, biography, language, Australiana, and any other quality books which the librarian and the library committee deem to be relevant to the collection."

Alas, no list of delegates' assigned subject headings for his speech was attached to the original draft. 